\title{
Association of IGFBP-3 gene polymorphism g. 3.930 G>A with birth size and birth weight in crossbred beef cattle
}

\author{
T. Hartatik ${ }^{1, *}$, D. A. Priyadi ${ }^{4}$, P. Panjono ${ }^{2}$, S. Bintara ${ }^{1}$, I. Ismaya ${ }^{1}$, I. G. S. Budisatria ${ }^{2}$, \\ B. P. Widyobroto ${ }^{2}$ and A. Agus ${ }^{3}$ \\ ${ }^{1}$ Department of Animal Breeding and Reproduction, Faculty of Animal Science, \\ Universitas Gadjah Mada \\ ${ }^{2}$ Departmen of Animal Production, Faculty of Animal Science, Universitas Gadjah Mada \\ ${ }^{3}$ Departmen of Animal Nutrition and Feed Science, Faculty of Animal Science, \\ Universitas Gadjah Mada, Jl. Fauna No. 3 Bulaksumur, Yogyakarta 55281 - Indonesia \\ ${ }^{4}$ Study Program of Livestock Product Processing Technology, Politeknik Negeri Banyuwangi, \\ Jl Raya Jember Km 13, Kabat, Banyuwangi 68461 - Indonesia \\ *CorrespondingE-mail: tety@ugm.ac.id
}

Received September 14, 2019; Accepted November 08, 2019

\begin{abstract}
ABSTRAK
Persilangan antar bangsa merupakan salah satu cara meningkatkan kualitas genetik sapi. Pengontrolan persilangan menggunakan marker genetik akan mempercepat proses tersebut. Gen IGFBP3 merupakan marker seleksi yang potensial, dikarenakan peranannya dalam mengatur pertumbuhan dan metabolisme pada sapi. Tujuan penelitian ini untuk melihat efek genotype terhadap berat dan ukuran saat lahir dengan menggunakan marker gen IBFBP-3.Total sampel sebanyak 32 ekor yang terdiri dari bangsa sapi Brahman Cross ( $\mathrm{n}=10$ ), dan hasil persilangan Brahman Cross dengan pejantan Belgian Blue $(\mathrm{n}=14)$ dan hasil persilangan Brahman Cross dengan pejantan Wagyu $(\mathrm{n}=8)$. Sekuen sepanjang $563 \mathrm{bp}$, meliputi sebagian intron 2, ekson 3, dan sebagian intron 3. Genotyping dilakukan dengan metode sekuensing dan metode PCR-RFLP dengan enzim restriksi PvuII. Hasil sekuensing mengidentifikasi sebuah SNP pada lokasi g. 3.930 (G>A). Teramati dua genotip, yaitu GA dan GG. Genotip tersebut tidak berpengaruh terhadap sifat lahir (bobot badan, panjang badan, tinggi gumba, lingkar dada) sapi penelitian. Bangsa sapi berpengaruh sangat nyata $(\mathrm{P}<0,01)$ terhadap keseluruhan sifat lahir. Kesimpulan dari penelitian ini bahwa berat dan ukuran tubuh sapi saat lahir dipengaruh oleh perbedaan bangsa penjantan yang digunakan dalam penelitian ini.
\end{abstract}

Kata kunci:Kata Kunci: IGFBP-3, persilangan sapi, SNP, sifat lahir, marker genetik

\begin{abstract}
Crossing between cattle breeds is the one way to improve the genetic quality of cattle. Controlling crosses using genetic markers will speed up the process. The IGFBP-3 gene is a potential marker of selection due to its role in regulating growth and metabolism in cattle. The aim of this study was to determine the effect of genotype on birth size and birth weight using IBFBP-3 gene marker. A total of 32 cattle consisted of 10 Brahman Cross cattle, 14 cattle results of Brahman Cross cow crosses with Belgian Blue bull, and 8 cattle results of Brahman Cross cow crosses with Wagyu bull. Sequences of $563 \mathrm{bp}$, including the part intron 2, exon 3, and the part intron 3. Genotyping was done by sequencing method and PCR-RFLP method with the restriction enzyme PvuII. An SNP was identified at location g.
\end{abstract}


3,930 (G>A). Two genotypes were observed, namely GA and GG. The genotype did not affect the performance of birth (body weight, body length, height at withers, heart girth) of the research sample. Birth traits are influenced by the cattle breed, it can be seen that Brahman Cross cattle have a body length that is bigger than the other crossbred .

Keywords: IGFBP-3, crossbred cattle, SNP, birth trait, genetic marker

\section{INTRODUCTION}

Genetic variation in the population of cattle is necessary to improve the ability of cattle for reaching the adaptability in new environment. However, the fact that trend on genetic variation parameter was decline recently (Biscarini et al., 2015). Improvement of the genetic quality such us a genetic variation of beef cattle can be rapidly achieved by crossbreeding method (Mrode et al., 2019). Crossbred cattle between the Taurins with Zebu are usually done, with the aim of taking the superior qualities of each breed (Roessler, 2019). Crossbreeding programs on beef cattle should be monitored by reviewing genes related to crossing purposes, and this is will improve the accuracy of the selection (Miller, 2010). Controlling the crossing with genetic markers will speed up the selection process because the selection is directed by the genetics data and be compared to the performance of visible phenotypes (Mrode et al., 2019). One of the potential genes that can be used as genetic marker on livestock is the Insulin-Like Growth Factor Binding Protein-3 (IGFBP-3) gene (Park et al., 2018; Rasouli et al., 2017; An et al., 2018; Ramesha et al., 2015; Choudhary et al., 2007). The IGFBP-3 protein controls the biological action of Insulin-Like Growth Factor-1 (IGF-1), whereas IGF-1 is a stimulant for division, growth, and survival of the cells. The controlled biological action of IGF-1 by IGFBP-3 may cause growth retardation, so IGFBP-3 is categorized as a growth inhibitor (Baxter, 2015; Baxter, 2002). The IGFBP-3 gene important role in growth traits led to research the relation of IGFBP-3 gene in livestock such as cattle, buffalo, sheep, goats, and pigs (Othman et al., 2018; Othman et al., 2014; Mahrous et al., 2015; Rajashekhara et al., 2018; Park et al., 2018; An et al., 2018; Rasouli et al., 2017). Genetic variations on IGFBP-3 gene were reported at Hanwoo (Cheong et al., 2008), Egyptian, FH, Chinese Simmental, Nanyang, Luxi Yellow cattle (Choudhary et al., 2007), Brahman, Brahman Cross (Priyadi et al., 2017). The genetic variations are located in intron 2 and statistically affect on cattle growth. SNP in IGFBP-3 genes have been reported to be recognized using restriction enzymes, such as HaeIII (Choudhary et al., 2007; Othman et al., 2014; Priyadi et al., 2017), NlaIII, and PvuII (Priyadi et al., 2017), each of which recognizes on a different SNP. There is a significant influence between SNP IGFBP-3 genes with economic characteristics, such as carcass weight and marbling score in Hanwoo (Cheong et al., 2008), and birth weight and weight at 12, 18, and 24 months in FH cattle and their crosses with Hariana (Choudhary et al., 2007). The performance of crossbred beef from Brahman Cross cow crosses with Belgian Blue bull and Wagyu bull have not been studied in previous research. This study aimed to better understand the effect of different IGFBP-3 genotype in the part of intron 2, whole exon 3, and the part of intron 3 base on PvuII restriction enzyme digestion on birth size and birth weight in crossbred beef cattle.

\section{MATERIALS AND METHODS}

\section{Sample}

This study used 32 samples, consisting of 8 Wagyu Bull Cross, 14 Belgian Blue Bull Cross, and 10 Brahman Cross, all samples are in the same age range. A single individual Wagyu and Belgian Blue bull used in the study, the mating was carried out by artificial insemination by estrus manipulation method.As for Brahman Cross, randomly natural mating occurred in the population. The cattle are kept in an open-wall pen and separated by each breed. The animals raised in Klaten, Central Java, Indonesia. Birth weight and birth size were collected shortly after the calf was born.

\section{Blood Sample and DNA Extraction}

Blood samples were collected using $10 \mathrm{ml}$ EDTA tubes, collected through aseptic jugular veins and then stored in a cold box at $10^{\circ} \mathrm{C}$ during the transportation. The blood samples were stored in the refrigerator at $-20^{\circ} \mathrm{C}$ until DNA extraction.

The DNA extraction was carried out using the gSYNCT DNA Extraction Kit (Geneaid, 
Taiwan), and the extraction procedure was following the manufacturer's recommendations. The result of the isolation process was tested using a horizontal gel (1\%) electrophoresis visualisation method, with ethidium bromide as the DNA dye. The electrophoresis apparatus is run at 100 volts for 15 minutes. The solution mixture consists of $1 \mu 1$ of DNA, $1 \mu 1$ of loading dye, and $4 \mu \mathrm{l}$ of $\mathrm{ddH}_{2} \mathrm{O}$.

\section{PCR Analysis}

DNA amplification using the PCR method with a thermal cycler machine. The PCR process used $0.5 \mu$ genomic DNA and $5 \mu \mathrm{l} \mathrm{PCR}$ mix solutions, each $0.5 \mu \mathrm{l}$ forward and reverse primers and $3.5 \mu \mathrm{dddH} 2 \mathrm{O}$. The primers produce $563 \mathrm{bp}$ IGFBP-3 gene fragments, including the part of intron 2 , whole exon 3 , and the part of intron 3 . The 14 sequences of the cattle IGFBP-3 gene referenced from the GenBank website (www.ncbi.nlm. nih.gov; GenBank accession No: KF899894, AY306011, DQ536398, AY601888, AY338971, DQ536397, JQ711181, NC_0073302.6, AC_000161, U83465, KF899893, DQ536399, AY3355439, AF305712)) were the basis for making primers (forward (5'-GCC TGG GTA TCC AGA GAT CA-3 ') and reverse (5'-GAT GGT GCT CAC CTG CTT TT-3'). The PCR process for the IGFBP-3 gene follows the previous researcher protocol (Othman et al., 2014) with modifications on the annealing temperature, which follows the temperature recommended by the primer's producer. The process begins with a pre-denaturation process at $94^{\circ} \mathrm{C}$ for five minutes, then followed by 35 reaction cycles consist of denaturation at $94^{\circ} \mathrm{C}$ for one minute, annealing at $56^{\circ} \mathrm{C}$ for one minute, extension at $72^{\circ} \mathrm{C}$ for one minute. After 35 cycles, the final extension process done at $72{ }^{\circ} \mathrm{C}$ for five minutes. The quality determination of the PCR results was done by visualised by horizontal agarose gel (2\%) electrophoresis at 1x TBE buffer and using $100 \mathrm{bp}$ ladder markers to measure the target DNA fragment size. Electrophoresis was done at 100 Volts for 15 minutes. Thick, clear, and consistent fragment size was desired PCR results, so it is feasible to proceed in the next process (genotyping).

\section{PCR-RFLP}

This research used the PvuII restriction enzyme. The PCR-RFLP process is done by adding 0.2 to $0.3 \mu 1$ of retraction enzymes, 3.2 to
$3.3 \mu \mathrm{ldd} \mathrm{d}_{2} \mathrm{O}, 1.5 \mu \mathrm{l}$ buffer enzymes in $8 \mu \mathrm{l}$ of PCR products, and incubated for four hours at $37^{\circ} \mathrm{C}$. Visualisation of PCR-RFLP results was done by electrophoresis on $8 \mu \mathrm{l}$ PCR-RFLP results with the addition of $3 \mu 1$ loading dye, and a $100 \mathrm{bp}$ marker ladder was used to identify the size of the PCR-RFLP fragment. Electrophoresis was done in 3\% agarose gel in $1 \times \mathrm{TBE}$ buffer at 100 Volts for 45 minutes.

\section{Genotyping and Statistical Analysis}

The sequencing process requires $30 \mu 1$ of PCR product and $20 \mu \mathrm{l}$ of forward primer. Sequencing was done by PT. Genetika Science Indonesia. Aligmnent study on 563 bp DNA sequences were conducted using the Bioedit software (ver.7.5.2). Sequencing was performed on Brahman Cross and Wagyu Bull Cross samples. The Belgian Blue Bull Cross genotyping process was carried out using the PCR-RFLP (PvuII restriction enzyme) method. The effect of birth traits and genotypes were analyzed using one way ANOVA. More generally, alleles frequency in the IGFBP-3 gene based on g. SNP $3,930(\mathrm{G}>\mathrm{A})$ can be formalized as :

$$
X i=\frac{2 n_{i i}+\sum_{j \neq i} n_{i j}}{2 n}
$$

(Nei, 1987)

When Xi represent the alleles frequency-i; $n_{i i}$ represent sum of population with $\mathrm{A}_{\mathrm{i}} \mathrm{A}_{\mathrm{i}}$ genotype; $n_{i j}$ represent sum of population with $A_{i} A_{j}$ genotype and $n$ represent total sample. Calculation of allele population based on Hardy-Weinberg (HW) Equilibrium was calculated statistically using the Chi-square test (Graffelman, 2015):

$$
X^{2}=\sum \frac{(O-E)^{2}}{E}
$$

When $\mathrm{X}^{2}$ represent Chi square test; O represent observed value, and $\mathrm{E}$ represent expected value.

\section{RESULTS AND DISCUSSION}

The genotyping results in 32 samples showed 2 genotypes in the IGFBP-3 (563 bp) gene. The genotype is denoted by the letters GA (heterozygote) and GG (homozygote). Polymorphism was observed in the nucleotide base number g.3,930 $(\mathrm{G}>\mathrm{A})$, in the intron 2 . Therefore the polymorphism is called SNPg.3,930(G>A). These results confirm of previous studies results in Brahman Cross cattle that reported SNP in the same position and could 
be identified by the restriction enzyme PvuII (Priyadi et al., 2017). Digestion using restriction enzyme PvuII showed two cutting patterns. Both homo- and heterozygote sequences in this study have the same product size $(563 \mathrm{bp})$ due to mutation is the transition of purine bases $(\mathrm{G}>\mathrm{A})$. Digestion in sequences with SNPg.3,930G (homozygote GG) formed a cutting site with a size of fragment 84 , and $479 \mathrm{bp}$. Individual sample with homozygote AA (SNPg.3,930A) performed two cutting sites with the size of fragment 84,88 , and $391 \mathrm{bp}$. DNA fragments with a size of 84 and 88 bp were not seen in visualisation with gel electrophoresis (Figure 1), due to its small size.

In this study, the AA genotype was not observed, but the genotype was observed in the previous (Priyadi et al., 2017) study in Brahman cattle $(n=4)$ and Brahman Cross cattle $(n=2)$. These results indicate that the AA homozygote genotype or A allele is a high-frequency allele occurrence in Zebu (Bos indicus) cattle. The results of this study show similar data with a previous study (Priyadi et al., 2017). This founding indicates that $\mathrm{A}$ allele is a characteristic allele of the Zebu blood influence, also seen that the cattle with Taurin's blood influence showed a higher frequency of GG genotype.

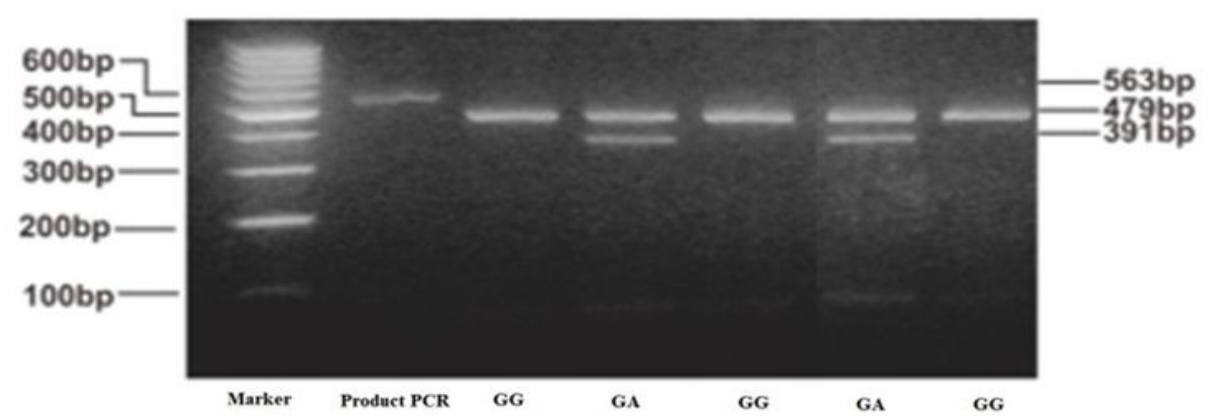

Figure 1. PCR-RFLP with PvuII Restriction Enzyme

Table1. Evaluation of Genetic Balance based on Hardy-Weinberg Equilibrium on IGFBP-3 Genes (563 bp)

\begin{tabular}{|c|c|c|c|c|c|c|c|}
\hline \multirow[t]{2}{*}{ Breeds } & & \multicolumn{3}{|c|}{ Genotype } & \multicolumn{2}{|c|}{$\begin{array}{c}\text { Allele Frequency } \\
(\%)\end{array}$} & \multirow{2}{*}{$\begin{array}{c}\mathrm{X}^{2} \\
\text { (P value) }\end{array}$} \\
\hline & & GG & $\mathrm{AG}$ & AA & $\mathrm{G}$ & A & \\
\hline \multirow[t]{2}{*}{ Wagyu Bull Cross } & Observed & 5 & 3 & 0 & 81.25 & 18.75 & 0.51 \\
\hline & Expected & 5.28 & 2.44 & 0.28 & & & \\
\hline \multirow[t]{2}{*}{ Belgian Blue Bull Cross } & Observed & 9 & 5 & 0 & \multirow{2}{*}{82.14} & \multirow{2}{*}{17.86} & \multirow{2}{*}{0.41} \\
\hline & Expected & 9.45 & 4.11 & 0.45 & & & \\
\hline \multirow[t]{2}{*}{ Brahman Cross } & Observed & 6 & 4 & 0 & \multirow{2}{*}{80.00} & \multirow{2}{*}{20.00} & \multirow{2}{*}{0.43} \\
\hline & Expected & 6.40 & 3.20 & 0.40 & & & \\
\hline & Average & & & & 81.13 & 18.87 & \\
\hline
\end{tabular}

If $\mathrm{X}^{2} \mathrm{P}<0.05$, not consistent with HW equilibrium 
Table 2. Average of Birth Traits for Three Different Breeds Genotype

\begin{tabular}{|c|c|c|c|c|c|c|}
\hline Breed & Genotype & $\mathrm{N}$ & $\mathrm{BL}(\mathrm{cm})$ & $\mathrm{HW}(\mathrm{cm})$ & $\mathrm{HG}(\mathrm{cm})$ & $\mathrm{BW}(\mathrm{kg})$ \\
\hline \multirow{3}{*}{ Wagyu Bull Cross } & GG & 5 & $52.40 \pm 2.07$ & $65.80 \pm 3.63$ & $64.40 \pm 3.44$ & $21.66 \pm 1.70$ \\
\hline & $\mathrm{AG}$ & 3 & $54.00 \pm 5.68$ & $64.33 \pm 3.79$ & $68.33 \pm 4.04$ & $21.57 \pm 2.83$ \\
\hline & Total & 8 & $53.00^{\mathrm{a}} \pm 3.46$ & $65.25^{\mathrm{a}_{ \pm}} .49$ & $65.88^{\mathrm{a}_{ \pm}} .94$ & $21.63^{\mathrm{a}} \pm 2.00$ \\
\hline \multirow{3}{*}{ Belgian Blue Bull Cross } & GG & 9 & $59.22 \pm 6.02$ & $73.33 \pm 4.00$ & $76.33 \pm 8.03$ & $30.56 \pm 7.47$ \\
\hline & $\mathrm{AG}$ & 5 & $57.00 \pm 7.81$ & $74.20 \pm 6.72$ & $75.20 \pm 5.72$ & $26.00 \pm 4.06$ \\
\hline & Total & 14 & $58.43^{\mathrm{b}} \pm 6.50$ & $73.64^{\mathrm{b}} \pm 4.89$ & $75.93 b^{ \pm 7.08}$ & $28.93^{b} \pm 6.67$ \\
\hline \multirow{3}{*}{ Brahman Cross } & GG & 6 & $63.67 \pm 5.13$ & $68.00 \pm 2.28$ & $73.17 \pm 5.08$ & $34.00 \pm 6.32$ \\
\hline & $\mathrm{AG}$ & 4 & $63.75 \pm 2.63$ & $71.13 \pm 5.95$ & $70.25 \pm 0.50$ & $30.00 \pm 4.08$ \\
\hline & Total & 10 & $63.70^{\mathrm{c}} \pm 4.11$ & $69.25^{\mathrm{a}} \pm 4.16$ & $72.00^{b_{ \pm}} \pm 4.08$ & $32.40^{c_{ \pm}} \pm 5.66$ \\
\hline \multirow{3}{*}{ Genotype } & GG & 20 & $58.85 \pm 6.43$ & $69.85 \pm 4.69$ & $72.40 \pm 7.80$ & $29.37 \pm 7.60$ \\
\hline & $\mathrm{AG}$ & 12 & $58.50 \pm 6.80$ & $70.71 \pm 6.74$ & $71.83 \pm 4.93$ & $26.23 \pm 4.81$ \\
\hline & Total & 32 & $58.72 \pm 6.47$ & $70.17 \pm 5.46$ & $72.19 \pm 6.78$ & $28.19 \pm 6.78$ \\
\hline
\end{tabular}

$\mathrm{BL}=$ body length; $\mathrm{HW}=$ height at withers; $\mathrm{HG}=$ heart girth ; $\mathrm{BW}=$ body weight

${ }^{a b c}$ Different superscript in the column show the significant differences at $\mathrm{P}<0.01$

The average frequency of $\mathrm{G}$ and $\mathrm{A}$ alleles in the cattle population in this study was $81.13 \%$ and $18.87 \%$, respectively (Table 1 ). In this study, the IGFBP-3 (563 bp) gene is polymorphic because it has an allele frequency of less than or equal to 0.99 (99\%) (Elston et al., 2012).

The genotype in the population is at equilibrium, according to HW law (Table 1), although matting in the crossing of Brahman Cross cows with Wagyu and Belgian Blue is not carried out randomly, as should be the condition of HW equilibrium (Graffelman, 2015). In this study, even if only one male was used in Wagyu and Belgian Blue case, the crossing was done for the first time in the population, there was no inbreeding, so it did not affect the allele frequency and HW equilibrium.

On this study, SNPg.3,930(G>A) on IGFBP3 genes showed no effect on body size at birth in animal samples (Table 2). Certain genotypic tendencies are better than others also not seen, although IGFBP-3 is one of the genes responsible for growth, it has a unique mechanism of work that is not yet fully known (Allard and Duan, 2018). IGFBP-3 has indirectly effect on cattle growth, unlike, for example, the Growth Hormone gene, which directly influences the cattle growth
(Hernández et al., 2016).

IGFBP-3 is a carrier protein whose one of its activity effect is to inhibit cell proliferation and pro-apoptosis (Baxter, 2001, 2015), with the mechanism as the main carrier (around $80 \%$ ) IGF1 protein that stimulates cell proliferation, the $20 \%$ left binded by other IGFBP (Turgut et al., 2006; Baxter, 2002). There are six variations of the IGFBP family (1-6), all of which have similar structures. IGFBP-3 is an IGF binding protein that has the highest concentration in serum or can be said to be the main its binding protein (Allard and Duan, 2018).

The IGFBP-3 pathway can be explained as follows, the stimulation of Growth Hormone (GH) causes the liver and local tissue to secrete Insulin-like Growth Factor-1 (IGF-1), which can act as endocrine, paracrine, and autocrine which stimulates cell growth, differentiation, proliferation, cell survival, etc (Ohlsson et al., 2009). Unbind IGF-1 has a half-life of $10 \mathrm{~min}$, will be longer if it binds to IGFBPs (25 min), and is more stable if it binds again with glycoprotein Acid Labile Subunits (ALS), the half-life will be 16 hours or more. The bonds held by IGFBP have the same or stronger affinity than Insulin-like Growth Factor-1 Receptor (IGF1R), so their role 
is critical in regulating IGF-1 activity (Allard and Duan, 2018). The SNPg.3,930(G>A) of IGFBP3 gene does not affect the birth trait. It can be made possible because the interaction of the prenatal environment is still similar (the same management system, feed, climate, etc.). The IGFBPs activity is highly influenced by the environment, especially for a postnatal individual, for example, the IGFBPs concentration will increase with hunger, stress, hypoxia, and amino acid shortages, and its will cause growth suppression (Allard and Duan, 2018).

As shown in the data (Table 2), the birth size was influenced by the breed, the largest body lenght performance $(\mathrm{P}<0.01)$ by Brahman Cross cows, Belgian Blue Bull Cross, Wagyu Bull Cross, sequentially. Brahman Cross which is high in Brahman blood is a type of cattle with a moderate to large frame size (Buchanan and Lenstra, 2015), with a long and deep body (Setyawan, 2016). The highest height at withers was showed by Belgian Blue Bull Cross $(\mathrm{P}<0.01)$, whereas in Brahman Cross and Wagyu Bull Cross cattle were no different. Wagyu Bull Cross heart girth beef was significantly smaller than the other two cattle breeds. This is normal due to the influence of Wagyu cattle blood which is characterised by having a small to medium frame size, while in other crossbred cattle it is affected by Belgian Blue and Brahman which have a medium to large frame size (Buchanan and Lenstra, 2015). Belgian Blue, Wagyu, and Brahman Cross have their own unique characteristics, so they have different raising goals. Belgian Blue produces lean meat, related to abnormalities in the myostatin gene, which codes for the growth of muscle protein and inhibits the growth of adipose cells (Albrecht et al., 2006). In contrast, Wagyu cattle have the goal of breeding to produce high-fat meat, especially the marbling (Gotoh et al., 2014). Whereas the Brahman Cross cattle, in contrast to the two previous cattle breeds that were characteristic of Taurin cattle, the Brahman Cross was selected towards its resistance to rough climate, poor grazing and more resistant to parasites and disease (Haque et al., 2011). A similar pattern of data was also shown in birth weight (Table 2), Wagyu Bull Cross cattle had the smallest performance $(\mathrm{P}<0.01)$ compared to the other two crossbred cattle. All three crossbred cattle have lower BW average performance than reported study. The average BW of Brahman Cross cattle was $35 \mathrm{~kg}$ (Holmes et al., 1992), Zebu-Wagyu crosses were
$28 \mathrm{~kg}$ (Hearnshaw et al., 2001), and Zebu-Belgian Blue crosses were $35 \mathrm{~kg}$ (Nogueira et al., 2016). Average cattle $\mathrm{BW}$ in this study tends to be smaller due to environmental factors, high temperatures as in tropical environments will reduce birth weight compared to temperate environments (Krishnan et al., 2017).

Single nucleotide polymorphism is located in the intron of the IGFBP-3 gene, so it does not change the amino acid composition of the IGFBP3 protein. So that SNPg.3,930(G>A) is classified as silence mutation. Mutations in the non-coding region do not cause changes in amino acids, but the presence of mutations in the gene promoter region may be possible to influence the work of the encoded protein, because it plays an important role in regulating gene expression, transcription and translation rates, post-transcription levels, also determines performance its RNA molecule, its stability, and its subcellular localization (Barrett et al., 2013). SNP gene IGFBP-3 at position 3,996 (intron 2) in the crossing of Bos taurus (Friesian Holstein) cattle with Bos indicus (Hariana) was reported to be significantly correlated in birth weight and post-weaning weight (Choudhary et al., 2007). SNPs in the promoter, 5'UTR, and intron region on the IGFBP-3 gene showed a significant effect on the economic trait of Hanwoo cattle (Cheong et al., 2008).

\section{CONCLUSION}

In the present study, the three cattle breed showed polymorphism in the IGFBP-3 gene (563 bp) comprising the part of intron 2, whole exon 3, and the part of intron 3. The SNPg.3,930(G>A) was found in the IGFBP-3 gene nucleotide location number 3,930, and these alleles form two genotypes (GG and GA). The genotype does not influence birth size and birth weight. The SNPg.3,930(G>A) can be identified using PvulI restriction enzyme. The Brahman Cross cows have the highest body lenght values, as well as the height at withers along with the Wagyu Bull Cross, and the heart girth along with the Belgian Blue Bull Cross.

\section{ACKNOWLEDGEMENT}

This research was funded by Basic Research Grant with the contract number: (2827/UN1/DITLIT/DIT-LIT/LT/2019). The authors are thankful to Retno Setyowati for 
technically help in laboratory analysis.

\section{REFERENCES}

Albrecht, E., F. Teuscher, K. Ender, and J. Wegner. 2006. Growth- And Breed-Related Changes Of Muscle Bundle Structure In Cattle. J. Anim. Sci. 84(11):2959-2964.

Allard, J.B. and C. Duan. 2018. IGF-Binding Proteins: Why Do They Exist And Why Are There So Many?. Front. Endocrinol. 9:117.

An, S.M., J.H. Hwang, S. Kwon, G.E. Yu, D.H. Park, G. Kang, T.W. Kim, H.C. Park, J. Ha, and C.W. Kim. 2018. Effect Of Single Nucleotide Polymorphisms In IGFBP2 And IGFBP3 Genes On Litter Size Traits In Berkshire Pigs. Anim. Biotechnol. 29(4):301-308.

Barrett, L.W., S. Fletcher, and S.D. Wilton. 2013. Untranslated Gene Regions and Other Noncoding Elements inBiochemistry and Molecular Biology. Springer, Basel.

Baxter, R.C. 2001. Signalling Pathways Involved In Antiproliferative Effects Of IGFBP-3 : A Review. Mol. Pathol. 54(3):145-148.

Baxter, R.C. 2002. Cellular Actions Of The Insulin-Like Growth Factor Binding Proteins. Endocr. Rev. 23(6):824-854.

Baxter, R.C. 2015. Nuclear Action Of InsulinLike Growth Factor Binding Protein-3. Gene. 569(1):7-13.

Biscarini, F., E. Nicolazzi, S. Alessandra, P. Boettcher, and G. Gandini. 2015. Challenges And Ppportunities In Genetic Improvement Of Local Livestock Breeds. Front. Genet. 6(33):1-7.

Buchanan, D.S., and J.A. Lenstra. 2015. Breeds of Cattle in The Genetic of Cattle $2^{\text {nd }}$ ed. A. Fries, R; Ruvinsky (ed.)., CAB International, Croydon.

Cheong, H.S., D. Yoon, L.H. Kim, B.L. Park, H.W. Lee, and S. Namgoong. 2008. Association Analysis Between Insulin-Like Growth Factor Binding Protein 3 (IGFBP3) Polymorphisms And Carcass Traits In Cattle. Asian Australas J. Anim. Sci. 21(3):309-313.

Choudhary, V., P. Kumar, T.K. Bhattacharya, B. Bhushan, A. Sharma, and A. Shukla. 2007. DNA Polymorphism Of Insulin-Like Growth Factor Binding Protein-3 Gene And Its Association With Birth Weight And Body Weight In Cattle. J. Anim. Breed. Genet. 124(1):29-34.
Elston, R., J. Satagopan, and S. Sun. 2012. Genetic Terminology. Methods Mol. Biol. 850:1-9.

Gotoh, T., H. Takahashi, T. Nishimura, K. Kuchida, and H. Mannen. 2014. Meat Produced By Japanese Black Cattle And Wagyu Meat Produced By Japanese Black Cattle And Wagyu. Anim. Front. 4(4):46-54.

Graffelman, J. 2015. Exploring Diallelic Genetic Markers: The HardyWeinberg Package. J. Stat. Softw. 64(3):1-23.

Haque, M.M., M.A. Hoque, N.G. Saha, A. Bhuiyan, M.M. Hossain, and M.A. Hossain. 2011. Selection Of Brahman CrossbredBreeding Bulls Based On Phenotypic Performance. Bangladesh J. Anim. Sci. 41(2):60-66.

Hearnshaw, H., D.W. Hennessy, P.L. Greenwood, G.S. Harper, and S. Morris. 2001. Gestation Length, Birth Traits And Pre-Weaning Growth Of Wagyu- , Piedmontese- And Angus- Sired Calves. Proc. Assoc. Advmt. Anim. Breed. Genet. 14:337-340.

Hernández, N., J. Martinez-Gonzalez, G. ParraBracamonte, A. Sifuentes-Rincon, N. LopezVillalobos, S. Morris, F. Briones-Encinia, E. Ortega-Rivas, V. Pacheco-Contreras, and L. Meza-García. 2016. Association Of Polymorphisms In Growth Hormone And Leptin Candidate Genes With Live Weight Traits Of Brahman Cattle. Genet. Mol. Res. 15(3):1-9.

Holmes, J.H., M.J. McKinnon, G.W. Seiferet, J.H. Schottler, A. Bannick, and A. Malik. 1992. Reproduction And Calf Growth In Brahman Crossbred And South East Asian Cattle In Papua New Guinea. Asian-Australasian J. Anim. Sci. 5(3):427-433.

Krishnan, G., M. Bagath, P. Pragna, M.K. Vidya, J. Aleena, P.R. Archana, V. Sejian, and R. Bhatta. 2017. Mitigation of the Heat Stress Impact in Livestock Reproduction in Theriogenology. InTech, London.

Mahrous, K.F., M.S. Hassanane, M.A. Mordy, and H.I. Shafey. 2015. Polymorphism Of Some Genes Associated With Meat-Related Traits In Egyptian Sheep Breeds. Iran. J. Appl. Anim. Sci. 5(3):655-663.

Miller, S. 2010. Genetic Improvement Of Beef Cattle Through Opportunities In Genomics. Rev. Bras. Zootec. 39:247-255.

Mrode, R., J.M.K. Ojango, A.M. Okeyo, and J.M. Mwacharo. 2019. Genomic Selection And Use Of Molecular Tools In Breeding 
Programs For Indigenous And Crossbred Cattle In Developing Countries: Current Status And Future Prospects. Front. Genet. 9:694.

Nogueira, G., K.S. Paulussi, A.T.H. Utsunomiya, Y.T. Utsunomiya, A. Almeida, A. Tanuri, T. Santos, and R. Alonso. 2016. Introgression Of The Belgian Blue Myostatin Variant Into Nellore Cattle: Effects Of Double Muscling On Birth Weight And Calving Ease. J. Anim. Sci. 99(1):150-151.

Ohlsson, C., S. Mohan, K. Sjögren, Å. Tivesten, J. Isgaard, O. Isaksson, J.O. Jansson, and J. Svensson. 2009. The Role Of Liver-Derived Insulin-Like Growth Factor-I. Endocr. Rev. 30(5):494-535.

Othman, O.E., A. Abou-eisha, and A.E. El-din. 2018. Study On Genetic Polymorphism Of IGFBP-3 Gene In Egyptian Buffalo. Annu. Res. Rev. Biol. 29(3):1-7.

Othman, O.E., S.S. Alam, and S.H.A. El-aziem. 2014. Single Nucleotide Polymorphism In Egyptian Cattle Insulin-Like Growth Factor Binding Protein-3 Gene. J. Genet. Eng. Biotechnol. 12(2):143-147.

Park, H., W. Lee, S. Chai, J. Woo, H. Chung, J. Park, and H. Song. 2018. Expression Of Insulin-Like Growth Factor Binding Protein3 And Regulation of The Insulin-Like Growth Factor-I Axis In Pig Testis. Biotechnol. Bioprocess Eng. 23(3):278-285.

Priyadi, D.A., Panjono, S. Bintara, and T. Hartatik. 2017. Genotype of Brahman And Brahman Cross Cattle Based On SNP In Insulin-Like Growth Factor Binding Protein-
3 (IGFBP-3) Gene Sequences. Biodiversitas. 18(2):795-800.

Rajashekhara, S., V.D. Pawar, M.P. Sawane, and R.S. Deshmukh. 2018. PCR-RFLP of IGFBP-3 Gene In Madgyal Sheep. Int. J. Sci. Environ. Technol. 7(3):801-808.

Ramesha, K.P., A. Rao, M. Basavaraju, G.R. Geetha, M.A. Kataktalware, and S. Jeyakumar. 2015. Genetic Variability of Bovine GHR , IGF-1 And IGFBP-3 Genes In Indian Cattle And Buffalo. S. Afr. J. Anim. Sci. 45(5):485-493.

Rasouli, S., A. Abdolmohammadi, A. Zebarjadi, and A. Mostafaei. 2017. Evaluation of Polymorphism In IGF-I And IGFBP-3 Genes And Their Relationship With Twinning Rate And Growth Traits In Markhoz Goats. Ann. Anim. Sci. 17(1):89103.

Roessler, R. 2019. Selection Decisions And Trait Preferences For Local And Imported Cattle And Sheep Breeds In Peri-/Urban Livestock Production Systems In Ouagadougou, Burkina Faso. Animals. 9(5):207.

Setyawan, A.D.W.I. 2016. Review : The Diversity of Local Cattle In Indonesia And The Efforts To Develop Superior Indigenous Cattle Breeds. Biodiversitas. 17(1):275-295.

Turgut, S., B. Kaptanoglu, G. Emmungil, and G. Turgut. 2006. Increased Plasma Levels of Growth Hormone, Insulin-Like Growth Factor (IGF)-I And IGF-Binding Protein 3 In Pregnant Rats With Exercise. Tohoku J. Exp. Med. 208(1):75-81. 